Jurnal Manajemen Bisnis dan Manajemen Informatika

Journal homepage: www.jurnal.stie-mandala.ac.id

E-ISSN 2774 - 2229

\title{
PENGARUH KUALITAS PRODUK,KUALITAS PELAYANAN DAN MEDIA SOSIAL TERHADAP KEPUTUSAN PEMBELIAN ( STUDI PADA UKM MAKARONI BANTET BANYUWANGI )
}

\author{
Husnul Hotimah ${ }^{\text {a }}$, Muhammad Firdaus ${ }^{\text {b }}$, Saiful Amin ${ }^{c}$ \\ ${ }^{a}$ Mahasiswa STIE Mandala Jember, husnulhotiman10@gmail.com \\ ${ }^{b}$ Dosen STIE Mandala Jember, firdaus@stie-mandala.ac.id \\ ${ }^{c}$ Dosen STIE Mandala Jember, saiful@stie-mandala.ac.id
}

E-mail Penulis Korespondensi :firdaus@stie-mandala.ac.id

\section{N F O A R T I K E L}

Riwayat Artikel:

Dikirim 19 Februari 2021

Direvisi 26 Maret 2021

Diterima 17 April 2021

Keywords:

Product Quality, Service

Quality, Social Media, and

Purchase

Decision.

Kata Kunci:

Kualitas produk, kualitas pelayanan, media sosial, dan keputusan pembelian.

\section{A B S T R A C T}

This study aims to determine the effect of product quality, service quality, and social media on purchasing decisions for macaroni bantet Banyuwangi. This study is based on quantitative methods, the data used in this study are primary data obtained from respondents' responses to questionnaires. Samples were taken as many as 100 respondents with a sampling technique using a simple random sample. The data obtained is then processed using SPSS analysis tools, analysis method using multiple linier regression analysis. The results showed that the variables of product quality, service quality, and social media had a simultaneous effect on purchasing decisions.

\section{A B S T R A K}

Penelitian ini bertujuan untuk mengetahui Pengaruh Kualitas Produk, Kualitas Pelayanan, dan Media sosial Terhadap Keputusan Pembelian Makaroni Bantet Banyuwangi. Penelitian ini didasarkan pada metode kuantitatif, data yang digunakan dalam penelitian ini berupa data primer yang diperoleh dari tanggapan responden terhadap kuesioner. Sampel yang diambil sebanyak 100 responden dengan teknik pengambilan sampel menggunakan sampel acak sederhana. Data yang diperoleh kemudian diolah menggunakan alat analisis SPSS, metode analisis menggunakan Analisis regresi linier berganda. Hasil penelitian menunjukkan bahwa variabel kualitas produk, kualitas pelayanan, dan media sosial berpengaruh secara simultan terhadap Keputusan pembelian. 


\section{PENDAHULUAN}

Di era globalisasi teknologi informasi setiap usaha harus memiliki pengetahuan tentang pemasaran agar tidak tertinggal dengan pesaing lain. Pemasaran dalam suatu usaha memegang peranan yang sangat penting, karena pemasaran merupakan salah satu kegiatan yang dilakukan untuk mempertahankan suatu usaha.

Usaha akan maju jika kualitas produk diminati oleh konsumen, kualitas produk berperan penting untuk memutuskan membeli barang dari kualitasnya. Dengan begitu pemilik usaha bisa mencapai tujuannya. Mempertahankan kualitas produk sangat penting untuk menjaga kepercayaan konsumen. Selain itu, kualitas pelayanan juga diperlukan untuk menarik daya minat pembeli sehingga para pembeli akan memutuskan untuk melakukan pembelian. Media sosial juga memiliki peran penting dalam meningkatkan minat pembeli. Dan juga dengan media sosial memudahkan konsumen untuk melihat produk-produk yang akan dijual atau dipromosikan oleh penjual, media sosial juga mudah di akses oleh semua kalangan.

Menurut Kotler dan Amstrong (2012:83) Kualitas produk adalah kemampuan suatu produk untuk melakukan fungsinya,meliputi daya tahan,keandalan,ketepatan, kemudahan serta atribut bernilai lainnya.

Kualitas pelayanan merupakan hal utama yang dapat memengaruhi keputusan pembelian, dengan kualitas pelayanan yang baik maka pembeli akan merasa puas dan akan melakukan pembelian ulang. Menurut Tjiptono dan Chandra (2012:77) menyatakan bahwa kualitas pelayanan mencerminkan perbandingan antara tingkat pelayanan yang disampaikan perusahaan dibandingkan ekspektasi konsumen. Pelayanan dapat dikatakan baik atau berkualitas apabila pelayanan yang diberikan oleh suatu perusahaan dapat memuaskan para konsumen.

Selain kualitas produk dan kualitas pelayanan juga dibutuhkan media sosial yang berguna untuk mengenalkan produk kepada pembeli, media sosial bisa di akses di mana saja yang memudahkan memasarkan produk tanpa bertemu langsung. Menurut Kotler (2015: 10), "adanya teknologi yang canggih dengan jaringan internet memudahkan interaksi secara langsung antara konsumen dan pelaku bisnis”. Apapun bisa dilakukan baik sekedar mencari informasi ataupun menjalankan bisnis.

Keputusan pembelian yaitu sebuah pendekatan penyelesaian masalah pada kegiatan manusia untuk membeli suatu barang atau jasa dalam memenuhi keinginan dan kebutuhannya (Swastha, 2015:34). 


\section{METODE PENELITIAN}

\section{Gambaran Obyek Penelitian}

Objek penelitian dalam skripsi ini adalah UKM Makaroni Bantet Banyuwangi yang tempatnya berada di Kalibaru. Makaroni Bantet adalah Usaha kecil dan menengah yang terletak di Banyuwangi tepatnya di Kalibaru yang berdiri sekitar 1 tahun yang lalu (2020). UKM Makaroni Bantet Banyuwangi berusaha memberikan kualitas produk dan pelayanan agar dapat meyakinkan pelanggan untuk memutuskan membeli Makaroni Bantet dan konsumen tidak kecewa, melakukan pembelian ulang di UKM Makaroni Bantet Banyuwangi. Variabel yang akan diteliti yaitu Kualitas pelayanan dan Media sosial terhadap Keputusan Pembelian.

\section{Populasi}

Populasi adalah wilayah generalisasi yang terdiri atas objek/subjek yang mempunyai kualitas dan karakteristik tertentu yang ditetapkan oleh peneliti untuk dipelajari dan kemudian ditarik kesimpulan (Sugiyono 2007). Dalam penelitian ini populasinya adalah konsumen Makaroni Bantet yang berada di Banyuwangi Jawa Timur.

\section{Sampel}

Sampel penelitian ini menggunakan ukuran sampel minimum dengan rumus indikator dikali 5, maka didapatkan hasil yaitu 5x20 (jumlah indikator pertanyaan dalam kuesioner) $=$ 100 sampel. (Ghozali 2008). Dengan teknik pengumpulan sampel menggunakan sampel acak sederhana (simple random sampling), yaitu konsumen makaroni bantet banyuwangi jawa timur. Sugiyono (2001:57) menyatakan definisi sampel acak sederhana (simple random sampling ) adalah teknik pengambilan sampel dari anggota populasi yang dilakukan secara acak tanpa memperhatikan strata (level) yang ada dalam populasi itu.

\section{Identifikasi Variabel Penelitian}

Variabel Bebas

Variabel bebas adalah variabel yang berpengaruh dan mempengaruhi variabel terikat yang bernotasi. Dalam penelitian ini variabel bebasnya adalah Variabel kualitas produk diberi notasi X1, Variabel kualitas pelayanan diberi notasi X2, Variabel media sosial diberi notasi $\mathrm{X} 3$.

Variabel Terikat

Variabel terikat merupakan faktor-faktor yang diamati dan diukur oleh peneliti dalam sebuah penelitian. Pada penelitian ini variabel terikatnya adalah variabel keputusan pembelian yang diberi notasi (Y). 


\section{Definisi Operasional Variabel}

1. Kualitas Produk (X1)

Kualitas produk adalah konsumen akan merasa puas bila hasil evaluasi mereka menunjukkan bahwa produk yang mereka gunakan berkualitas (Lupiyoadi, 2001:158)

Adapun indikator menurut Zeithaml (1988) dalam (Nugroho Setiadi 2003) menyatakan kualitas produk dibentuk oleh beberapa indikator antara lain:
a. Kinerja (Performance)
b. Keistimewaan tambahan (Features)
c. Kehandalan (Reliability)
d. Daya tahan (Durability)

2. Kualitas Pelayanan (X2)

Kualitas pelayanan merupakan isu krusial bagi setiap perusahaan, apapun bentuk produk yang dihasilkan. Kualitas layanan secara sederhana bisa diartikan sebagai ukuran seberapa bagus tingkat layanan yang diberikan mampu sesuai dengan ekspektasi pelanggan, Lewis and Booms dalam Tjiptono (2008: 85).

Adapun indikator kualitas pelayanan menurut Tjiptono dan Chandra (2012: 75),.meliputi:
a. Bentuk fisik (tangible)
b. Keandalan (reliability)
c. Daya tangkap (responsiveness)
d. Jaminan (assurance)
e. Empati (empathy)

3. Media sosial (X3)

Menurut Kotler dan Keller (2016;642) mendefinisikan media sosial sebagai alat atau cara yang dilakukan oleh perusahaan untuk membagikan informasi berupa teks, gambar, audio, dan video kepada orang lain dan konsumen atau sebaliknya Adapun indikator menurut (Khatib, 2016) yaitu
a. Adanya konten yang menarik dan menghibur
b. Adanya interaksi antara konsumen dengan penjual
c. Adanya interaksi antara konsumen dengan konsumen lain
d. Kemudahan untuk pencarian informasi produk
e. Kemudahan untuk mengkomunikasikan informasi pada publik
f. Tingkat kepercayaan pada media sosial 


\section{Keputusan Pembelian (Y)}

Keputusan pembelian merupakan sikap seseorang untuk membeli atau menggunakan suatu produk baik berupa barang atau jasa yang telah diyakini akan memuaskan dirinya dan kesediaan menanggung resiko yang mungkin ditimbulkanya. Keputusan pembelian yang diambil oleh pembeli sebenarnya merupakan kumpulan dari sejumlah keputusan yang terorganisir (Adirama Aldi 2012).

Adapun Indikator menurut pandangan Kotler dan Keller (2016:194-201) :

a. Konsumen memiliki kebutuhan yang dapat dipenuhi oleh perusahaan

b. Konsumen mengumpulkan informasi mengenai kebutuhan yang dapat dipenuhi oleh perusahaan

c. Konsumen memilih perusahaan dibanding pesaing

d. Konsumen memutuskan membeli produk yang disediakan oleh perusahaan

e. Konsumen merasa puas setelah membeli produk perusahaan

\section{Metode Pengumpulan Data}

1. Wawancara

Teknik pengumpulan data yang dilakukan dengan cara tatap muka dan melakukan tanya jawab secara langsung antara peneliti dan responden. Melakukan wawancara dengan owner Makaroni Bantet Banyuwangi.

\section{Kuesioner}

Teknik pengumpulan data yang dilakukan dengan memberi pertanyaan secara tertulis kepada responden untuk mendapatkan jawaban dari responden terhadap pertanyaan yang diajukan. Menyebarkan kuesioner terhadap konsumen Makaroni Bantet Banyuwangi

3. Observasi

Teknik pengumpulan data yang dilakukan dengan memberi pertanyaan secara tertulis kepada responden untuk mendapatkan jawaban dari responden terhadap pertanyaan yang diajukan

4. Dokumentasi

Teknik pengumpulan data dengan dokumentasi adalah metode yang lebih mudah daripada metode-metode lain karena jika ada kekeliruan, sumber datanya masih tetap. Objek yang diamati pada metode dokumentasi bukanlah benda hidup melainkan benda mati. Sesuai namanya, dokumentasi berasal dari kata dokumen yang berarti barang-barang tertulis. Dokumen dalam penelitian ini berupa data penjualan Makaroni Bantet Banyuwangi. 


\section{ANALISIS HASIL PENELITIAN}

\section{Uji Instrumen Data}

Menganalisis data dengan menggunakan angka-angka yang didapat dari penentuan skor untuk memudahkan perhitungan.

a. Uji Validitas

Merupakan data yang bertujuan untuk mengetahui sejauh mana validitas data yang diperoleh dari penyebaran kuesioner, uji validitas data dapat dilakukan dengan menghitung korelasi antar masing-masing pertanyaan dengan skor total pengamatan (Arikunto, 2006:178).

b. Uji Realibilitas

Reliabilitas adalah suatu nilai yang menunjukan konsistensi suatu alat pengukur di dalam mengukur gejala yang sama. Setiap alat pengukur seharusnya memiliki kemampuan untuk memberikan hasil pengukuran yang konsisten. Pengujiannya digunakan rumus alpha sebagai berikut ( Arikunto, 2006:164 )

\section{Uji Asumsi Klasik}

Bertujuan untuk mengetahui apakah model regresi yang diperoleh dapat menghasilkan estimator linier yang baik, Uji asumsi klasik terdiri dari :

a. Uji linieritas

Uji linearitas bertujuan untuk mengetahui apakah dua variabel mempunyai hubungan yang linear atau tidak secara signifikan. selain itu uji linieritas ini juga diharapkan dapat mengetahui taraf signifikansi penyimpangan dari linieritas hubungan tersebut, apabila penyimpangan yang ditemukan tidak signifikan, maka hubungan antara variabel bebas dengan variabel tergantung adalah linier. Ghozali,(2011:167-168).

b. Uji Normalitas

Menurut Ghozali (2016:71) uji normalitas dilakukan untuk menguji apakah pada suatu model regresi, suatu variabel independen dan variabel dependen ataupun keduanya mempunyai distribusi normal atau tidak normal.

c. Uji multikolinieritas

Multikolinieritas dapat dideteksi dapat dilihat dari nilai tolerance VI ( variance Inflation Factor ), tolerance mengukur variabilitas variabel independen yang terpilih yang tidak dijelaskan oleh variabel independen lainnya, jadi nilai toleransi yang rendah sama dengan nilai VIF tinggi (karena $\mathrm{VIF}=1 /$ tolerance), multikolinieritas terjadi apabila nilai tolerance lebih kecil dari 0,10 dan nilai VIF lebih besar dari 10,00, Ghozali (2016:103). 


\section{d. Uji Heteroskedastisitas}

Dasar pengambilan keputusan pada uji heteroskedastisitas dengan menggunakan uji glejser yakni :

a. Jika nilai signifikansi lebih besar dari 0,05 kesimpulannya tidak terjadi heteroskedastisitas.

b. Jika nilai signifikansi lebih kecil dari 0,05 kesimpulannya terjadi heteroskedastisitas.

\section{Analisis Regresi Berganda}

Analisis regresi linear berganda digunakan oleh peneliti, bila peneliti meramalkan bagaimana keadaan (naik turunnya) variabel dependen (kriterium), bila dua atau lebih variabel independen sebagai faktor predictor dimanipulasi (dinaik turunkan nilainya. Jadi analisis regresi berganda akan dilakukan bila jumlah variabel independennya minimal 2 (Sugiyono 2017:275).

\section{Analisis Koefisien Determinasi $\left(R^{2}\right)$}

Untuk mengukur besarnya pengaruh variabel bebas $(\mathrm{X})$ terhadap variabel terikat $(\mathrm{Y})$ digunakan rumus, menurut Supranto (2001:57) :

\section{Hipotesis}

Uji hipotesis adalah metode pengambilan keputusan yang didasarkan dari analisis data, baik dari percobaan yang terkontrol, maupun dari observasi (tidak terkontrol).

a. Uji t

Untuk menguji hipotesis tentang koefisien-koefisien slope regresi secara individual, mudah digunakan karena menjelaskan perbedaan-perbedaan unit-unit pengukuran variabel-variabel dan definisi standar dari koefisien-koefisien yang diestimasi, (Sarwoko, 2005:65)

b. Uji F

Uji-F adalah suatu cara menguji hipotesis nol yang melibatkan lebih dari satu koefisien, cara bekerjanya adalah dengan menentukan apakah kecocokan dari sebuah persamaan regresi berkurang secara signifikan dengan membatasi persamaan tersebut untuk menyesuaikan diri terhadap hipotesis nol, (Sarwoko, 2005:72) 


\section{HASIL DAN PEMBAHASAN}

\section{Uji Instrumen Data}

\section{a. Uji Validitas}

Berdasarkan hasil uji validitas dapat di ketahui hasil pengujian vaiditas menunjukan seluruh pernyataan yang digunakan pada kuisioner penelitian ini valid dan dapat digunakan sebagai instrumen data penelitian.

\section{b. Uji Realibilitas}

Berdasarkan hasil uji realibilitas memperoleh nilai cronbach's alpha diatas 0,60 dan nilai relative konsisten sehinggan dapat di artikan bahwa instrumen yang digunakan dalam penelitian ini reliabel.

\section{Uji Asumsi Klasik}

\section{a. Uji Linieritas}

Berdasarkan hasil pengujian linieritas, dapat diketahui bahwa model memiliki nilai signifikansi lebih besar dari 0,05. Artinya model penelitian ini terdapat hubungan yang linier.

\section{b. Uji Normalitas}

Berdasarkan hasil pengujian normalitas, dapat diketahui bahwa nilai signifikansi asymp sig (2-tailed) sebesar 0.95 lebih besar dari 0.05 , maka sesuai dasar pengambilan keputusan dalam uji normalitas kolmogorov-smirnov di atas, dapat disimpulkan bahwa data berdistribusi normal. Dengan demikian asumsi atau persyaratan normalitas dalam model regresi sudah terpenuhi.

\section{c. Uji Multikolinieritas}

Berdasarkan hasil analisis Collinearity Statistics yang dapat diketahui bahwa model tidak terjadi multikolinieritas. Hal tersebut ditandai dengan nilai VIF $<10$ dan tolerance $>0,1$.

\section{d. Uji Hereroskedastisitas}

Berdasarkan data hasil glejser dapat diartikan bahwa di dalam analisis regresi tidak terdapat gejala heteroskedastisitas karena menunjukan nilai signifikan ( $p$ value) variabel kualitas produk 0.506 , kualitas pelayanan 0.424 dan media sosial 0.186 , hasil tersebut dengan jelas menunjukan bahwa tidak satupun variabel independen yang signifikan secara statistik mempengaruhi variabel dependen nilai ABS_RES hal tersebut di karenakan nilai profabilitas signifikannya yang diatas 0,05 atau $5 \%$. 


\section{Analisis Regresi Linier Berganda}

Berdasarkan hasil regresi linier berganda diperoleh persamaan sebagai berikut:

$$
\begin{gathered}
Y=\alpha+b 1 X 1+b 2 X 2+b 3 X 3+\varepsilon \\
\mathrm{Y}=10.735+0,079 \mathrm{X} 1-0,192 \mathrm{X} 2+0,543 \mathrm{X} 3+e
\end{gathered}
$$

Nilai Konstanta

Dari persamaan diatas yang berarti bahwa jika nilai dari variabel terikat Kualitas Produk, Kualitas Pelayanan dan Media sosial tetap/konstan, maka Keputusan Pembelian (Y) nilainya sebesar 10.735 .

Kualitas Produk (X1)

Nilai koefisien dari variabel Kualitas Produk adalah tidak berpengaruh dengan nilai sebesar 0,079, hal ini berarti bahwa semakin rendah Kualitas Produk yang dimiliki makaroni bantet maka akan semakin rendahnya Keputusan Pembelian Makaroni Bantet Banyuwangi.

Kualitas Pelayanan (X2)

Nilai koefisien dari variabel Kualitas Pelayanan adalah tidak berpengaruh dengan nilai sebesar $(-0,192)$, hal ini berarti bahwa semakin rendah Kualitas Pelayanan yang dimiliki makaroni bantet maka akan semakin rendahnya Keputusan Pembelian Makaroni Bantet Banyuwangi.

Media sosial (X3)

Nilai koefisien dari variabel Media sosial adalah terdapat pengaruh dengan nilai sebesar 0,543, hal ini berarti bahwa semakin tinggi Media sosial yang dimiliki makaroni bantet maka akan semakin meningkatkan Keputusan Pembelian Makaroni Bantet Banyuwangi.

\section{Analisis Koefisien Determinasi $\left(R^{2}\right)$}

Berdasarkan Analisis Koefisien Determinasi $\left(R^{2}\right)$ menunjukkan nilai Adjusted $\mathrm{R}$ Square $=0,286$. Hal ini menunjukkan bahwa model regresi ini mampu menjelaskan variasi pengaruh variabel Kualitas Produk (X1), Kualitas Pelayanan(X2) dan Media sosial(X3) terhadap Keputusan Pembelian (Y) sebesar 28,6\%. sedangkan sisanya sebesar $71,4 \%$ dijelaskan oleh variabel lainnya yang tidak diteliti pada penelitian ini seperti variabel harga, promosi, lokasi, citra merek, iklan, inovasi produk, word of mount, kepuasan konsumen, desain dan kepercayaan konsumen.

\section{Uji Hipotesis}

Uji hipotesis adalah metode pengambilan keputusan yang didasarkan dari analisis 
data, baik dari percobaan yang terkontrol, maupun dari observasi (tidak terkontrol).

\section{a. Uji t}

1) Kualitas Produk (X1) terhadap variabel Keputusan Pembelian (Y)

Hasil analisis regresi berganda melalui uji t, menunjukkan bahwa t_hitung pada variabel Kualitas Produk (X1) sebesar 0,596 dan t_tabel sebesar 1.984. selain itu nilai signifikansi adalah sebesar 0,553 lebih besar dari 0,05 (tingkat kepercayaan 95\%), dengan demikian dapat disimpulkan bahwa H0 ditolak atau Ha diterima. artinya kualitas Produk tidak berpengaruh secara parsial terhadap Keputusan Pembelian.

2) Kualitas Pelayanan (X2) terhadap variabel Keputusan Pembelian (Y)

Hasil analisis regresi berganda uji t, menunjukkan bahwa t_hitung pada variabel Kualitas Pelayanan(X2) sebesar -1.633 dan t_tabel sebesar 1.984 dan dapat dilihat dalam tabel Sig 0,106 lebih besar 0,05, maka $\mathrm{H} 0$ ditolak atau $\mathrm{Ha}$ diterima, artinya kualitas Pelayanan tidak berpengaruh secara parsial terhadap Keputusan Pembelian.

3) Media sosial (X3) terhadap variabel Keputusan Pembelian (Y)

Hasil analisis regresi berganda uji t, menunjukkan bahwa t_hitung pada variabel Media sosial (X3) sebesar 6.515 dan t_tabel sebesar 1.984 dan dapat dilihat dalam tabel Sig 0,000 lebih kecil 0,05, maka H0 diterima dan $\mathrm{Ha}$ ditolak, artinya media sosial berpengaruh secara parsial terhadap Keputusan Pembelian..

\section{b. Uji F}

Berdasarkan Uji F menunjukan model ini memiliki nilai signifikansi sebesar 0,000 lebih kecil dari 0.05, maka model ini signifikan dan dapat digunakan untuk menguji hipotesis dengan tingkat kepercayaan $95 \%$.

Berdasarkan hasil uji F sebagai berikut. Nilai $F_{\text {hitung }}$ sebesar 14,229 dengan kriteria pengujian maka $F_{\text {hitung }}$ sebesar 14,229 $>F_{\text {tabel }}$ sebesar 2,70 yang artinya secara statistik dapat dibuktikan bahwa variabel independen kualitas produk $\left(\mathrm{X}_{1}\right)$, kualitas pelayanan $\left(\mathrm{X}_{2}\right)$, media sosial $\left(\mathrm{X}_{3}\right)$, secara simultan berpengaruh signifikan dan positif terhadap keputusan pembelian Makaroni Bantet Banyuwangi. 


\section{Interpretasi}

A. Pengaruh Kualitas Produk terhadap Keputusan Pembelian Makaroni Bantet Banyuwangi.

Berdasarkan hasil pengujian hipotesis menunjukkan bahwa kualitas produk tidak berpengaruh secara parsial terhadap Keputusan pembelian artinya semakin rendah kualitas produk maka tidak dapat meningkatkan Keputusan Pembelian.

Faktor yang menyebabkan kualitas produk tidak berpengaruh secara parsial terhadap Keputusan pembelian, karena owner di Makaroni Bantet Banyuwangi kurang memberikan cita rasa yang beragam terhadap Makaroni Bantet, dengan hasil penelitian ini diharapkan owner lebih memperhatikan kualitas produk atau meningkatkan lebih baik lagi kualitas produk agar konsumen lebih sering membeli Makaroni Bantet untuk mencapai tujuan yang diharapkan.

\section{B. Pengaruh Kualitas Pelayanan terhadap Keputusan Pembelian Makaroni Bantet Banyuwangi.}

Berdasarkan hasil pengujian hipotesis menunjukkan bahwa kualitas pelayanan tidak berpengaruh secara parsial terhadap Keputusan pembelian artinya semakin rendah kualitas pelayanan maka tidak dapat meningkatkan Keputusan Pembelian.

Faktor yang menyebabkan kualitas pelayanan tidak berpengaruh secara parsial terhadap Keputusan Pembelian, karena konsumen yang membeli makaroni Bantet merasa pelayanan yang diberikan kurang baik dari penjual, dengan hasil penelitian ini diharapkan owner lebih memperhatikan kualitas pelayanan atau meningkatkan lebih baik lagi kualitas pelayanan agar konsumen lebih sering membeli dan senang terhadap Makaroni Bantet untuk mencapai tujuan yang diharapkan.

\section{Pengaruh Media sosial terhadap Keputusan Pembelian Makaroni Bantet Banyuwangi.}

Berdasarkan hasil pengujian hipotesis menunjukkan bahwa media sosial berpengaruh secara parsial terhadap Keputusan pembelian artinya semakin baik dan mudah pada media sosial maka dapat meningkatkan Keputusan Pembelian.

Faktor yang menyebabkan media sosial dapat berpengaruh secara parsial terhadap keputusan pembelian, karena konsumen Makaroni Bantet Banyuwangi setuju promosi yang ditawarkan penjual sangat menghibur dan menarik di media sosial, dengan hasil penelitian ini diharapkan media sosial Makaroni Bantet Banyuwangi semakin bertambah baik dan terus meningkat agar dapat menghasilkan banyak peminat untuk mencapai tujuan utama UKM Makaroni Bantet 
Banyuwangi.

D. Pengaruh Kualitas Produk, Kualitas Pelayanan dan Media sosial terhadap Keputusan Pembelian Makaroni Bantet Banyuwangi.

Berdasarkan hasil pengujian hipotesis menunjukkan bahwa Kualitas Produk, Kualitas Pelayanan dan Media sosial secara simultan berpengaruh secara signifikan terhadap Keputusan pembelian artinya semakin baik pada Kualitas Produk, Kualitas Pelayanan dan Media sosial maka dapat meningkatkan Keputusan Pembelian.

Berdasarkan beberapa variabel yang mempengaruhi keputusan pembelian di antaranya Kualitas Produk, Kualitas Pelayanan dan Media sosial bahwa memang secara simultan tiga variabel tersebut mempengaruhi keputusan pembelian Makaroni Bantet Banyuwangi, bisa dikatakan mereka dapat merasakan perubahan jika tiga variabel tersebut benar-benar diterapkan dengan baik dan sesuai dengan yang diinginkan di Makaroni Bantet Banyuwangi.

\section{SIMPULAN}

Berdasarkan pembahasan penelitian secara umum mengenai "Pengaruh Kualitas Produk, Kualitas Pelayanan dan Media sosial terhadap Keputusan Pembelian (studi pada UKM Makaroni Bantet Banyuwangi)" dapat disimpulkan bahwa :

1. Variabel kualitas produk tidak berpengaruh signifikan terhadap Keputusan Pembelian Makaroni Bantet Banyuwangi.

2. Variabel kualitas pelayanan tidak berpengaruh signifikan terhadap Keputusan Pembelian Makaroni Bantet Banyuwangi.

3. Variabel media sosial berpengaruh signifikan terhadap Keputusan Pembelian Makaroni Bantet Banyuwangi.

4. Variabel Kualitas Produk, Kualitas Pelayanan dan Media sosial berpengaruh signifikan terhadap Keputusan Pembelian Makaroni Bantet Banyuwangi. 


\section{DAFTAR PUSTAKA}

Adirama Aldi, 2012. Pengaruh Citra Merek dan Kualitas Produk Terhadap Keputusan Pembelian Konsumen.Hal 21. Universitas Negeri Yogyakarta. Yogyakarta.

Ghozali, I. 2006. Aplikasi Analisis Multivariate Dengan Program SPSS. Edisi Pertama. Badan Penerbit Universitas Diponegoro. Semarang. . 2008. Aplikasi Analisis Multivariate Dengan Program SPSS. Semarang: Badan penerbit Universitas diPonegoro.

i, Imam. (2008). Structural Equation Modelling, Edisi II, Universitas Diponegoro, Semarang.

. 2011. Aplikasi Analisis Multivariate Dengan Program IBM SPSS Cetakan Kelima.Badan Penerbit Universitas Diponegoro. Semarang. . 2010. Aplikasi Analisis Multivariate Dengan Program SPSS. Edisi Kedua. Badan Penerbit Universitas Diponegoro. Semarang. 2013. Aplikasi Analisis Multivariate Dengan Program IBM SPSS 21 Update PLS Regresi.Badan Penerbit Universitas Diponegoro. Semarang. , Imam. 2016. Aplikasi Analisis Multivariate Dengan Program IBM SPSS 23 (Edisi 8). Cetakan ke VIII. Semarang : Badan Penerbit Universitas Diponegoro.

Kotler Philip dan Amstrong Gary 2012, Prinsip Prinsip Pemasaran Edisi 13 Jilid 1 Jakarta :Erlangga

Kotler, (2015). Manajemen Pemasaran Edisi Milenium. Jakarta : PT. Prehalindo.

Kotler, Philip dan Kevin L. Keller. 2016. Marketing Management, 15 th edition. United States: Pearson Education.

Khatib, F. (2016). The impact of social media charac-teristics on purchase decision empirical study of Saudi customers in Aseer Region. International Journal of Business and Social Science, 7(4), 41-50.

Lupiyoadi, Rambat. 2001. Manajemen Pemasaran Jasa, Salemba Empat, Jakarta. 
Sugiyono, 2001. Metode Penelitian, Bandung: CV Alfa Beta. 2007. Metode Penelitian Kuantitatif Kualitatif dan R\&D. Bandung: Alfabeta. (2017). Metode Penelitian Kuantitatif, Kualitatif, dan R\&D. Bandung : Alfabeta, CV.

Setiadi, J. Nugroho (2003). Perilaku Konsumen: Konsep dan Implikasi untuk Strategi dan penelitian pemasaran. Jakarta: Prenada Media.

Sarwoko. 2005. Dasar-dasar Ekonometrika, Yogyakarta : Penerbit PT. ANDI

Tjiptono Fandy, 2008. Service Management, Mewujudkan Layanan Prima, Andy, Yogyakarta.

Tjiptono, Fandy dan G. Chandra. 2012. Pemasaran Strategik. Edisi 2. Andi Offset. Yogyakarta. 